12th LUMEN International Scientific Conference Rethinking Social Action. Core Values in Practice | RSACVP 2019 | 15-17 May 2019 | lasi-

Romania

\title{
Bridging the Gap Between the Real and the Ideal English Teacher in Romanian Technical Higher Education
}

\author{
Anca GRECULESCU, Liliana-Luminița TODORESCU
}

https://doi.org/10.18662/lumproc. 160

How to cite: Greculescu, A., \& Todorescu, L.-L. (2019). Bridging the Gap Between the Real and the Ideal English Teacher in Romanian Technical Higher Education. In C. Ignatescu (ed.), 12th LUMEN International Scientific Conference Rethinking Social Action. Core Values in Practice, 15-17 May 2019, Iasi Romania (pp. 133-140). Iasi, Romania: LUMEN Proceedings. https://doi.org/10.18662/lumproc.160 



\title{
Bridging the Gap Between the Real and the Ideal English Teacher in Romanian Technical Higher Education
}

\author{
Anca GRECULESCU1*, Liliana-Luminița TODORESCU² \\ Abstract
}

The current study capitalizes on previous research regarding the English teacher's profile as outlined by Romanian college schoolchildren and engineering students. This extensive study aims to line up engineering students' expectations of their English teacher with the requirements of the English teacher profession in Romanian technical higher education. What is the current English teacher like in technical higher education? What are their main characteristics likely to ensure the students' appreciation? What makes it an ideal English teacher in technical higher education? How big is the gap between the real and ideal teacher profiles? Does the profile of the real English teacher meet the requirements of this profession in technical higher education? The characteristics of an ideal English language teacher have proved of keen interest internationally. Nevertheless, fen relevant studies have been conducted on this topic in Romanian technical education from a student perspective. Hence, the growing need to outline a profile of the ideal English language teacher as perceived by Romanian engineering students.

Keywords: English teacher profile; technical higher education; real/ ideal teacher; personal quality.

\section{Introduction}

Within the literature that we have been surveying, there has, however, been little research into the real and ideal features of the English teacher. Likewise, little research has addressed the engineering students' perceptions of the English teacher in Romanian technical higher education.

\footnotetext{
1 Ph.D. Lecturer, University Politehnica of Bucharest, Bucharest, Romania, anca.greculescu@upb.ro.

2 Ph.D. Lecturer, University Politehnica of Timişoara, Timişoara, Romania, lilitodorescu@yahoo.com.
} 
It is worth mentioning that an engineering student's language performance is highly affected not only by his or her personality factors and volition but also by the language instructor's own personality, motivation and skills.

In English language teaching within technical higher education, ideal teachers may differ in terms of "language proficiency, teaching styles, personality traits and teaching materials". [1:20]

Moreover, the characteristics of an ideal English teacher include subject knowledge, skills and distinctive personality characteristics. The question is how much of these characteristics engineering students perceive and expect from their language teachers? To what extent personality traits prevail over language knowledge and didactic skills?

Research reveals that the characteristics that most likely trigger students' educational performance are the ones depicted as "purposeful, aim-oriented, relaxed, warm, supportive, a sense of order and humour, embodied in teacher in order to make him an ideal" [2: 104].

Hence, there is growing importance of the teacher's profile in technical higher education since the teacher is required to use more flexible and varied pedagogical methods, to regularly evaluate and adjust the pedagogical modes of delivery, to encourage a sense of autonomy in the learner, while ensuring adequate guidance and support. Furthermore, the academic teacher is likely to promote mutual respect within the learnerteacher relationship and to devise appropriate procedures for dealing with students' needs and expectations.

\section{Problem Statement}

The present study is based on previous research on quality assurance and the English teacher profile in technical higher education, conducted between 2010-2012 [3: 700]. The research targeted high school children in their last year of study at "Nicolae Ciorănescu" technical college, in Târgovişte. Moreover, the target group was also made of students in their first and second academic years, from the Faculty of Electrical Engineering, Mechanical Engineering and Power Engineering, within Universities "Politehnica" of Bucharest and "Politehnica" of Timişoara. [3: 700]. The study narrowed down the main features of an ideal English teacher likely to ensure their language and professional performance as well as the quality of the educational process.

It seems fitting to use the previous research to pause and reflect on the gap between the real and ideal profiles of the Romanian English teacher 
performing in technical higher education. Such a reflection should be a springboard for creativity, for the creation of completely new language teaching prerequisites and resources where a gap can be identified, or for consideration of how existing language teaching resources might be combined, adapted and rendered fit-for-purpose to address the current challenges, in an era of global accountability and international standards, of unprecedented and rapid change - geopolitical, economic and technical. All of this places pressure on national technical education systems as they work to improve the efficiency and effectiveness of language learning and teaching in increasingly multilingual and multicultural classrooms.

\section{Research Questions/Aims of the research}

Since the previous research revealed as the main characteristics identified by both target groups humour, punctuality, ability to socialize and professional competence and even leniency, interpreted as the teacher's tolerance towards their mistakes, the question posed is to what extent these personality traits are still displayed by English teachers in technical education.

Do engineering students still expect these traits from their English language teachers? How big is the gap between engineering students' expectations from their English teachers?

Engineering students' conceptions of their English teacher were explored more closely in the present study in order to match their conceptions with the already existing profiles. Furthermore, the question posed is whether these profiles are likely to ensure the quality of language teaching and learning in technical higher education in Romania. If we identify the characteristics of an ideal English teacher in technical higher education, we will be able to match these two profiles and thus, meet the students' expectations that will bring about better language performance.

\section{Research Methods}

The research was conducted on 218 students, studying different branches of engineering (electrical engineering, electronics and Information Technology, computer science, applied engineering and telecommunications) at Universities "Politehnica" of Bucharest $(57.9 \%)$, "Politehnica" of Timişoara (13.4\%), and "Valahia" of Târgovişte (28.7\%), in 2018. 
First, a focus group was carried out in order to find out the opinions of the target group regarding the characteristics of the Romanian English teacher. Subsequently, the data garnered from an on-line questionnaire were analysed statistically.

Two questions were addressed regarding students' perceptions of their real versus ideal English teachers in technical higher education.

What are the 3 most important characteristics of an IDEAL English teacher in Technical Higher Education nowadays?

\section{Findings}

Most answers were provided by students in their second year of study $(56.2 \%)$ as opposed to alumni in their first academic year $(25.3 \%)$. This is an important aspect since new entries are not expected to have formed a clearer perception of their English teacher at the very beginning of their academic life.

Engineering students have identified the following characteristics as shown in Table 1:

Table 1. Characteristics of IDEAL English Teachers in Romanian Technical Education -List of items proposed by students

\begin{tabular}{|l|l|}
\hline intelligent & empathetic \\
\hline friendly & communicative \\
\hline dedicated/devoted & professional \\
\hline didactic & $\begin{array}{l}\text { outstanding (better than expected, } \\
\text { excellent) }\end{array}$ \\
\hline funny & real \\
\hline innovative & motivated \\
\hline creative & smart \\
\hline joyful & open-minded \\
\hline resourceful & disciplined \\
\hline active & patient \\
\hline kind & indulgent \\
\hline confident & realistic \\
\hline humorous & calm \\
\hline demanding & cool \\
\hline
\end{tabular}


Anca GRECULESCU et al. | Lumen Proceedings 9 | RSACVP2019

\begin{tabular}{|l|l|}
\hline nice & serious \\
\hline understanding & interesting \\
\hline engaged & charismatic \\
\hline entertaining & fair \\
\hline wise & $\begin{array}{l}\text { soft-hearted (kind, feeling sympathy for } \\
\text { students) }\end{array}$ \\
\hline handsome & helpful \\
\hline responsible & pleasant \\
\hline organized & respectful \\
\hline good-listener & imaginative \\
\hline $\begin{array}{l}\text { inspirational } \\
\text { knowledgeable }\end{array}$ & leader \\
\hline $\begin{array}{l}\text { witted skilled at using } \\
\text { hords in a clever and } \\
\text { humorous way; having wit } \\
\text { or understanding }\end{array}$ & relaxed \\
\hline
\end{tabular}

The figures show the following top three main characteristics:

Communicative (53.7\%); - by which students understand the teacher's willingness to talk to them and give them information. Moreover, it implies openness on the teacher's part and his/her availability to communicate with the students, actively listen to and respond their queries.

Friendly (34.3\%); - interpreted as behaving in a pleasant kind way to students and synonymous with kind, pleasant, amiable, congenial, open and sociable.

Dedicated/Devoted (24.5\%) - interpreted by students as "believing that his/her activity (mainly the teaching activity and the relationship with students) is very important and the teacher allots quality time and energy to it".

Other important features identified were intelligent $(24.1 \%)$; cool $(23.1 \%)$ - interpreted as being fashionable and attractive; open-minded (22.7\%) receptive to new different ideas and opinions; funny $(22.2 \%)$; motivated $(22.2 \%)$ and nice $(22.2 \%)$ - synonymous with polite and kind.

The second questioned addressed was:

What 3 words would you use to describe REAL English teachers (in technical higher education) nowadays?

Students have identified the following characteristics as shown in Table 2. 
Anca GRECULESCU et al. | Lumen Proceedings 9 | RSACVP2019

Table 2. Characteristics of REAL English Teachers (in general) - List of items proposed by students

\begin{tabular}{|l|l|}
\hline boring & devoted \\
\hline nice & open-minded \\
\hline professional & friendly \\
\hline active & kind \\
\hline stiff & smart \\
\hline authoritative & empathetic \\
\hline disciplined & responsible \\
\hline communicative & funny \\
\hline charming & tolerant \\
\hline helpful & creative \\
\hline good & beautiful \\
\hline passionate & disciplined \\
\hline inspirational & interactive \\
\hline different & understanding \\
\hline stiff & old-fashioned \\
\hline international & bilingual \\
\hline cute & optimistic \\
\hline dishonest & unreliable \\
\hline serious & patient \\
\hline good listener & independent thinker \\
\hline reliable & sociable \\
\hline expert & resourceful \\
\hline motivated & cool \\
\hline mature & sweet \\
\hline quick & respectful \\
\hline wise & helpful \\
\hline prepared & dedicated \\
\hline composed & tenacious \\
\hline intelligent & happy \\
\hline
\end{tabular}




\begin{tabular}{|l|l|}
\hline didactic & entertaining \\
\hline calm & \\
\hline
\end{tabular}

Engineering students consider that nowadays, the English teachers in technical higher education prove to be:

Nice $(52.6 \%)$ - interpreted as synonymous with kind, friendly and sociable, good and helpful; communicative (33.4\%); intelligent $(24.2 \%)$ - also perceived as synonymous with smart and wise. Engineering students have also characterized their real English teachers as funny/fun; cute, cool and sweet $(21.2 \%)$ and active $(20.3 \%)$. However, a very low percentage of students consider their real English teacher to be stiff and authoritative, boring and oldfasbioned (1.5\%).

\section{Conclusions}

The current research figures show there is no big gap between the real and ideal profiles of the English teacher in Romanian technical high education. In an ideal language teaching and learning context, the English teacher must prove communicative, friendly and dedicated/devoted to their work and relationship with their students. More precisely, the English teacher is expected to prove dedication and resourcefulness as well as goalorientation towards achieving the students' academic performance.

Nevertheless, the research findings reveal that Romanian engineering students admit that, in reality, the English teacher is "nice, communicative and intelligent". In addition, the English teacher is characterized as a warm and caring human being who wants all students to be proficient learners and who fosters a congenial motivating classroom atmosphere likely to meet his/her students' educational needs.

As far as the communicative trait is concerned, students emphasize the importance of interaction (talking and responding) and consider it the basis of learning and teaching. Another common feature for both profiles is friendliness and humor, highly appreciated by students.

It becomes worth mentioning that language teachers, English teachers in particular, and in line with the requirements of the subject taught, have proved and still prove creativity and open-mindedness towards the design and use of various innovative language teaching methods and tools.

Moreover, they are willing to go beyond the prerequisites of language teaching and learning and display a "humane" character, depicted as sociable, funny and nice. 
All in all, the findings of the current research bridge the gap between the real and ideal profiles of English teachers in Romanian technical higher education

Furthermore, it reveals the shift from English teachers' aptitudes (language skills) to their attitudes (personality traits), from a matter of intellectual to an affective preparation, from the teacher' abilities to his or her personality.

In line with the central explanation for the importance of the English teacher's profile and second language study is the assumption that "personality factors can be regarded as tools to guide teachers to choose the right way of teaching", most likely to ensure engineering students' language performance. [4: 17].

\section{References}

[1] Huang Z. What Makes a Successful EFL Teacher in China? A case Study of an English Language Teacher at Nanjing University of Chinese Medicine. English Language Teaching. 2010;3(3):20-28. Available online https://files.eric.ed.gov/fulltext/EJ1081836.pdf

[2] Aç1kgoz F. A Study on teacher characteristics and their effects on their students attitudes. The Reading Matrix. 2005;5(2):103-115. Available online http://www.readingmatrix.com/articles/acikgoz/article.pdf.

[3] Greculescu A, Todorescu L. Quality Assurance and the English Teacher's Profile in Romanian Technical Higher Education. Procedia Social and Behavioral Studies. 2014;143:698-703. Available online https://core.ac.uk/download/pdf/82542789.pdf

[4] Norfazlika Abd. Karim, Dzeelfa Zainal Abidin, Siti Nur Dina Mohd Ali. Personality Factors and Second Language Acquisition: An Islamic Viewpoint. International Journal of Business, Economics and Law. 2016;11(5):12-19. ISSN 2289-1552. Available online: http://ijbel.com/wpcontent/uploads/2017/03/IJBEL-37.pdf 